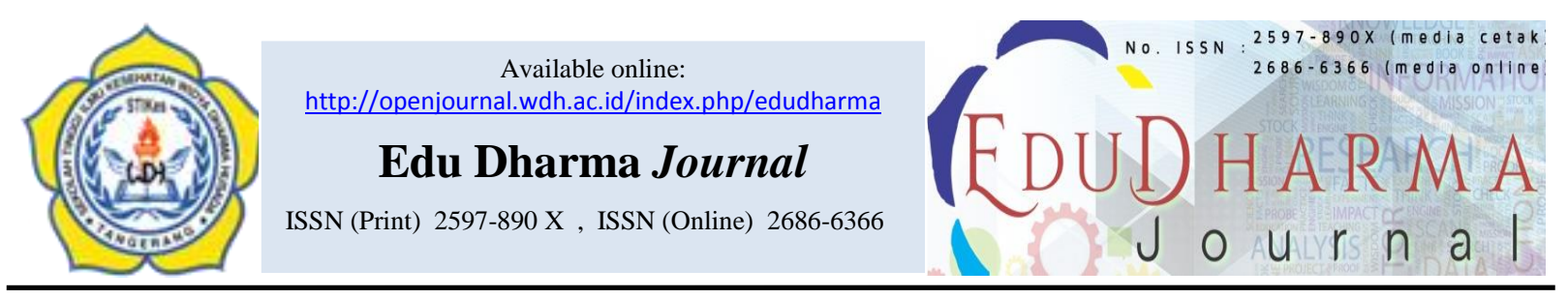

\title{
HUBUNGAN LAMA MENJALANI TERAPI HEMODIALISIS DENGAN KUALITAS HIDUP PASIEN PENYAKIT GINJAL KRONIK DI RUANG HEMODIALISA RUMAH SAKIT DR SITANALA TANGERANG
}

\author{
Dewi Fitriani ${ }^{1^{*}}$, Rita Dwi Pratiwi ${ }^{2}$, Roni Saputra ${ }^{3}$, Katarina Silvia Haningrum ${ }^{4}$ \\ 1,2,4 STIKes Widya Dharma Husada Tangerang, Jalan Pajajaran No.1, Pamulang, Tangerang Selatan 15417, Indonesia \\ ${ }^{3}$ Rumah Sakit Umum Kabupateng Tangerang, Indonesia
}

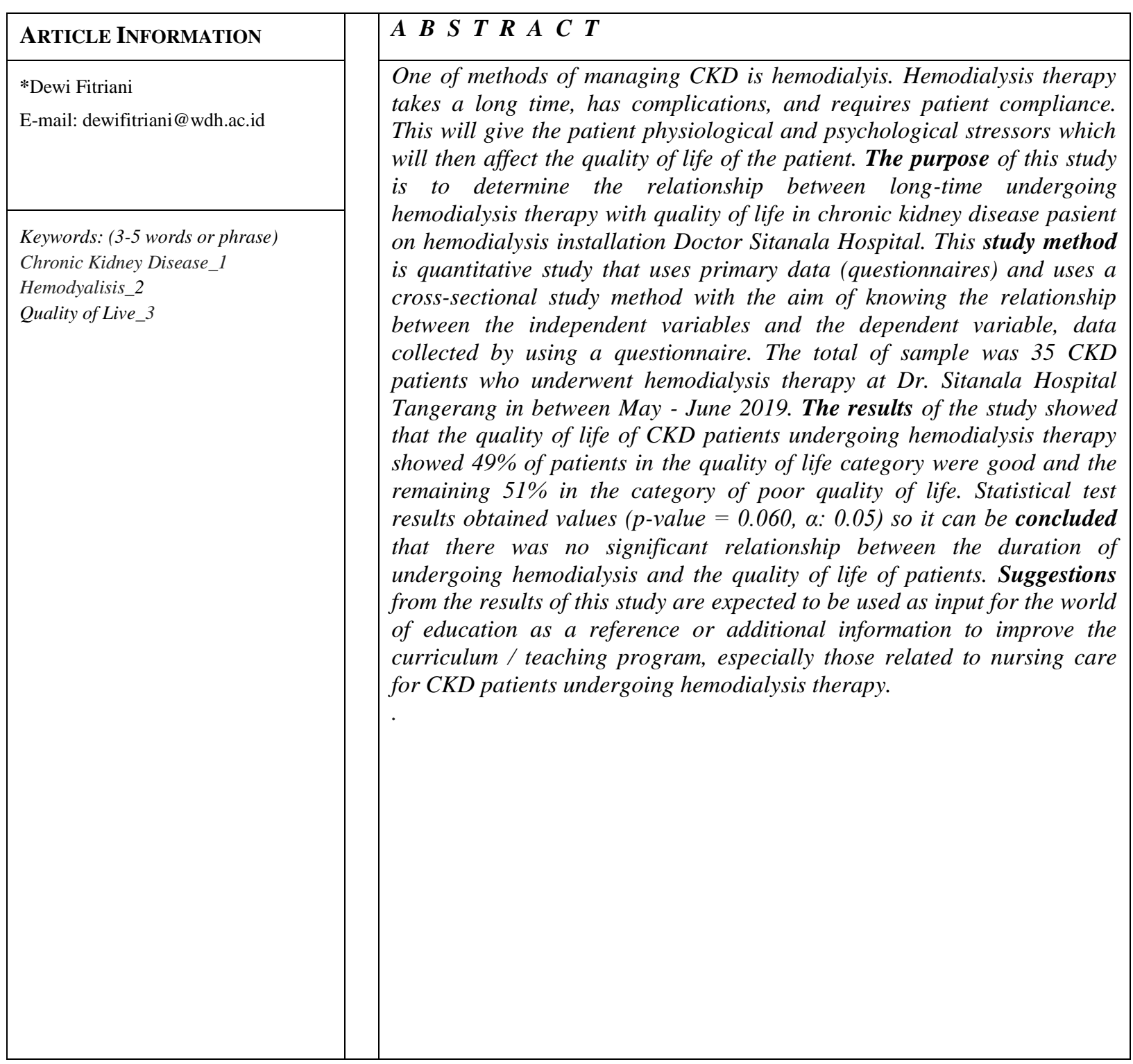




\begin{tabular}{|c|c|}
\hline \multirow[t]{3}{*}{$\begin{array}{l}\text { Kata Kunci: (3-5 kata atau frase) } \\
\text { Penyakit Ginjal Kronik_1 } \\
\text { Hemodialisa_2 } \\
\text { Kualitas Hidup_3 }\end{array}$} & $\begin{array}{l}\text { A B S T R A K } \\
\text { Salah satu metode penatalaksanaan Penyakit Ginjal Kronik adalah dengan } \\
\text { cara hemodialis. Terapi hemodialisis membutuhkan waktu yang lama, } \\
\text { memiliki komplikasi, dan membutuhkan kepatuhan pasien. Hal ini akan } \\
\text { memberikan stressor fisiologis dan psikologis pasien yang kemudian akan } \\
\text { mempengaruhi kualitas hidup pasien. Tujuan penelitian ini adalah untuk } \\
\text { mengetahui hubungan lama menjalani terapi hemodialisis dengan kualitas } \\
\text { hidup pasien PGK di ruang hemodialisa RS Dr Sitanala Tangerang. } \\
\text { Metode penelitian ini merupakan penelitian kuantitatif yang } \\
\text { menggunakan data primer (kuesioner) dan memakai metode penelitian } \\
\text { cross sectional dengan tujuan untuk mengetahui hubungan antara } \\
\text { variabel independen dengan variabel dependen, data yang dikumpulkan } \\
\text { dengan cara menggunakan kuesioner. Jumlah sampel sebanyak } 35 \text { pasien } \\
\text { penyakit ginjal kronik yang mejalani terapi hemodialisis di RS Dr Sitanala } \\
\text { Tangerang antara bulan Mei- Juni tahun 2019. Dari hasil penelitian } \\
\text { diperoleh hasil kualitas hidup pasien PGK yang menjalani terapi } \\
\text { hemodialisis menunjukkan } 49 \% \text { pasien pada kategori kualitas hidup baik } \\
\text { dan sisanya 51\% pada kategori kualitas hidup buruk. Hasil uji statistik } \\
\text { diperoleh nilai (p-value=0,060, } \alpha \text { : } 0,05 \text { ) maka dapat di simpulkan bahwa } \\
\text { tidak ada hubungan yang signifikan antara lama menjalani hemodialisis } \\
\text { dengan kualitas hidup pasien. Saran dari hasil penelitian ini diharapkan } \\
\text { dapat dijadikan bahan masukan bagi dunia pendidikan sebagai referensi } \\
\text { atau tambahan informasi untuk meningkatkan kurikulum/ program } \\
\text { pengajaran terutama yang berkaitan dengan asuhan keperawatan pada } \\
\text { pasien PGK yang menjalani terapi hemodialisis. }\end{array}$ \\
\hline & This is an open access article under the $\mathrm{CC}-\mathrm{BY}-\mathrm{NC}-\mathrm{SA}$ license. \\
\hline & (1) 2020 Some rights reserved \\
\hline
\end{tabular}




\section{PENDAHULUAN}

Penyakit ginjal kronis (PGK) merupakan gangguan kesehatan masyarakat global dengan prevalensi dan insiden gagal ginjal yang meningkat, prognosis yang buruk dan biaya pengobatan yang tinggi. Prevalensi Penyakit ginjal kronis meningkat seiring meningkatnya jumlah penduduk usia lanjut akibat lanjut kejadian penyakit diabetes melitus serta hipertensi. Sekitar 1 dari 10 populasi global mengalami PGK pada stadium tertentum (Infodatin, 2017).

Hasil systematic review dan meta-analysis yang dilakukan oleh Hill et al pada tahun 2016, mendapatkan prevalensi global Penyakit ginjal kronis sebesar 13,4\%.4 Menurut hasil Global Burden of Disease tahun 2010, Penyakit ginjal kronis merupakan penyebab kematian peringkat ke-27 di dunia tahun 1990 dan meningkat diurutan ke-18 pada tahun 2010. Sedangkan di Indonesia, prevalensi gagal ginjal kronik sebesar 2\% ( 499.800 orang ). Perawatan penyakit ginjal merupakan ranking kedua denga biaya terbesar dari BPJS kesehatan setelah penyakit jantung (Infodatin, 2017).

Penyakit ginjal kronis merupakan penurunan progresif fungsi ginjal dalam beberapa bulan atau dalam hitungan tahun. Penyakit ginjal kronis didefinisikan sebagai kerusakan ginjal dan atau penurunan Glomerular Filtration Rate (GFR) kurang dari 60ml/min/I,73m2 selama minimal 3 bulan (Kidney Disease: Improving Global Outcomes, KDIGO $2012) 3$

Menurut Nur pada tahun 2012, dimana salah satu metode terapi dari Penyakit ginjal kronis adalah dengan cara hemodialisis atau biasa disebut cuci darah.

Hemodialisis adalah proses dilakukannya pembersihan darah dari akumulasi sampah buangan. Hemodialisis digunakan bagi pasien dengan tahap akhir gagal ginjal atau pasien yang berpenyakit akut yang membutuhkan dialisis waktu singkat. Hemodialisis bukan untuk menyembuhkan penyakit ginjal kronik, tetapi terapi pengganti fungsi ginjal untuk membersihkan darah dari berbagai macam zat- zat sampah yang tidak bisa dikeluarkan secara alami pada pasienpasien Penyakit ginjal kronis karena menurunnya atau rusaknya fungsi ginjal penderita.

Menurut data Indonesia Renal Registry ( IRR ) pada tahun 2017, jumlah pasien Penyakit ginjal kronis dengan piihan terapi hemodialisa di Indonesia dari tahun ke tahun semakin bertambah. Pada tahun 2017 terdapat 77.892 pasien hemodialisa 
yang tersebar di 433 unit Hemodialisa di Indonesia. Dengan adanya bantuan pembiayaan pemerintah melalui program BPJS Kesehatan, diprediksi jumlah dari pasien cuci darah akan semakin bertambah di tahun-tahun yang mendatang. Menurut Nuari dan Widayati pada tahun 2017 tujuan dari pengobatan hemodialisa adalah meningkatkan kualitas hidup pasien.13 Tetapi, dalam proses hemodialisa yang berlangsung dengan durasi $4-5$ jam selama 2 -3 / minggu, dan dilakukan seumur hidup tentu saja akan mempengaruhi kondisi fisik juga psikologis pada pasien Penyakit ginjal kronis dengan hemodialisa. Sedangkan kualitas hidup terdiri dari beberapa aspek kualitas sekaligus, atau antara lain aspek kondisi fisik, psikologis, sosial dan juga lingkungan dalam kehidupan sehari hari (Mabsusah, 2016 ). Menurut penelitian sebelumnya yang dilakukan oleh Sari pada tahun 2017 yang dilakukan di Unit Hemodialisa RS Abdul Moeluk Medan, dari 97 klien terdapat 40 pasien Penyakit ginjal kronis ( $41,2 \%)$ yang sudah melalui Hemodialisis lebih dari 24 bulan. Dimana hasilnya 13 pasien memiliki kualitas hidup mejadi baik sedangkan 27 pasien memiliki kualitas hidup buruk.

Berdasarkan studi pendahuluan yang dilakukan dilaksanakan penelitian sampai bulan Juni 2019, tardapat 48 pasien Penyakit ginjal kronis yang menjalani HD rutin di RS Dr Sitanala Tangerang yang belum diketahui bagaimana kualitas hidupnya seteleh menjalani terapi hemodialsisis selama beberapa tahun. Dari hasil beberapa wawancara terhadap pasien, rata-rata pasien memiliki keluhan gangguan tidur dan nyeri badan yang merupakan salah satu dari aspek kondisi fisik dalam menilai kualitas hidup. Bahkan ada satu pasien yang meninggal dunia setelah menjalani hemodialisis selama 14 bulan. Berdasarkan latar belakang di atas, peneliti tertarik untuk melakukan penelitian dengan judul "Hubungan lama menjalani terapi hemodialisis dengan kualitas hidup pasien penyakit ginjal kronik di ruang hemodialisa RS Dr Sitanala Tangerang".

\section{METODE PENELITIAN}

Jenis penelitian ini adalah studi analitik observasional dengan rancangan cross sectional. Variabel independen adalah lamanya menjalani terapi HD, sedangkan variabel dependen adalah kualitas hidup pada pasien PGK dengan. Penelitian dilakukan pada bulan Maret 2019 di Ruang Hemodialisa RS Dr Sitanala Tangerang.

Populasi penelitian ini adalah Total sampling pasien Penyakit ginjal kronis 
yang menjalani HD di Ruang Hemodialisa RS Dr Sitanala Tangerang. Sampel penelitian yang dipilih adalah subjek yang diambil dari populasi studi dengan metode purposive sampling yang memenuhi kriteria inklusi dan tidak memiliki kriteria eksklusi. Kriteria inklusi subjek: bersedia menjadi responden, pasien penyakit ginjal kronik yang menjalani hemodialisis rutin 2 kali seminggu dan pasien dalam kesadaran compos mentis. Kriteria eksklusi subjek: usia lebih dari 65 tahun, memiliki gangguan indra pendengaran atau penglihatan dan pasien dengan gangguan psikiatri.

Hasil studi diperoleh dengan cara wawancara menggunakan kuesioner dengan menggunakan Kuesioner Kidney Disease Quality of Life Short Form 1.3 (KDQOL-SF 1.3) untuk menentukan kualitas hidup pasien Penyakit ginjal kronis yang menjalani HD.Data dianalisis secara statistik berdasarkan variabel yang dinilai menggunakan sistem komputerisasi yaitu analisis univariat dan bivariat. Analisis univariat dilakukan untuk melihat distribusi frekuensi dari masing-masing variabel independen dan variabel dependen. Analisis bivariat dilakukan untuk menganalisis hubungan antara variabel independen dan variabel dependen. Hubungan dua variabel tersebut dianalisis dengan menggunakan uji Chisquare dan dikatakan bermakna bila $\mathrm{p}<$ 0,05 .

\section{HASIL PENELITIAN}

Penelitian ini dilakukan terhadap 35 orang pasien Penyakit ginjal kronis yang menjalani hemodialisis di Ruang Hemodialisa RS Dr Sitanala Tangerang. pada bulan Maret 2019

Tabel 1. Distribusi Frekuensi Usia Responden di RS DR Sitanala

\begin{tabular}{lll}
\hline Usia & Frekuensi & $\begin{array}{l}\text { Prosentase } \\
(\%)\end{array}$ \\
\hline$<40$ tahun & 4 & 11 \\
\hline $\begin{array}{l}40-50 \\
\text { tahun }\end{array}$ & 11 & 32 \\
\hline$>50$ tahun & 20 & 57 \\
\hline Jumlah & 35 & 100 \\
\hline
\end{tabular}

Berdasarkan Tabel 1 didapatkan hasil lebih dari setengah sebanyak 20 responden dengan hasil $57 \%$ usia $>50$ tahun.

Tabel 2. Distribusi Frekuensi Jenis Kelamin Responden di RS DR Sitanala

\begin{tabular}{lll}
\hline Jenis Kelamin & $\begin{array}{l}\text { Frekuensi } \\
(\mathrm{n})\end{array}$ & $\begin{array}{l}\text { Prosentase } \\
(\%)\end{array}$ \\
\hline Laki-laki & 18 & 51 \\
\hline Perempuan & 17 & 49 \\
\hline Jumlah & 35 & 100 \\
\hline
\end{tabular}

Berdasarkan tabel 2 didapatkan lebih dari setengah sebanyak 18 responden $(51 \%)$ laki-laki. 
Tabel 3. Distribusi Frekuensi Lama Menjalani Terapi Hemodialisis Responden di RS DR Sitanala

\begin{tabular}{lll}
\hline $\begin{array}{l}\text { Lama } \\
\begin{array}{l}\text { Menjalani } \\
\text { Terapi } \\
\text { Hemodialisis }\end{array}\end{array}$ & Frekuensi & $\begin{array}{l}\text { Prosentase } \\
(\%)\end{array}$ \\
\hline$<2$ tahun & 16 & 46 \\
\hline$\geq 2$ tahun & 19 & 54 \\
\hline Jumlah & 35 & 100 \\
\hline
\end{tabular}

Berdasarkan tabel 3 didapatkan hasil lebih dari setengah sebanyak 19 responden dengan hasil $54 \%$ sudah menjalanai terapi hemodialisis selama $\geq 2$ tahun.
Tabel 4. Distribusi Frekuensi Kualitas Hidup Responden di RS DR Sitanala

\begin{tabular}{lll}
\hline $\begin{array}{l}\text { Kualitas } \\
\text { Hidup } \\
\text { Pasien }\end{array}$ & Frekuensi & $\begin{array}{l}\text { Prosentase } \\
(\%)\end{array}$ \\
\hline Baik & 17 & 49 \\
\hline Buruk & 18 & 51 \\
\hline Jumlah & 35 & 100 \\
\hline
\end{tabular}

Berdasarkan tabel 4 didapatkan hasil lebih dari setengah sebanyak 18 responden dengan hasil $51 \%$ memiliki kualitas hidup yang buruk.

Tabel 5. Distribusi Frekuensi Hubungan Lama Menjalani Hemodialisis dengan Kualitas Hidup Pasien Penyaki Ginjal Kronis di RS DR Sitanala

\begin{tabular}{|c|c|c|c|c|c|c|c|}
\hline \multirow{2}{*}{ Variabel } & \multicolumn{4}{|c|}{ Kualitas Hidup } & \multirow{2}{*}{ Jumlah } & \multirow[b]{2}{*}{$\%$} & \multirow{2}{*}{$p$-value } \\
\hline & Baik & $\%$ & Buruk & $\%$ & & & \\
\hline $\begin{array}{l}\text { Masa HD } \\
<2 \text { tahun }\end{array}$ & 5 & 19 & 11 & 27 & 16 & 46 & \multirow{3}{*}{0.060} \\
\hline$\geq 2$ tahun & 12 & 30 & 7 & 24 & 19 & 54 & \\
\hline Jumlah & 17 & 49 & 18 & 51 & 35 & 100 & \\
\hline
\end{tabular}

Hasil uji statistik menggunakan Chi Square Test diperoleh nilai $\mathrm{p}=0,060$ $(\mathrm{p}>0,05)$. Berdasarkan hasil tersebut dapat disimpulkan secara statistik bahwa tidak terdapat hubungan yang bermakna antara lama hemodialisis dengan kualitas hidup pada pasien Penyakit ginjal kronis di Ruang Hemodialisa RS Dr Sitanala Tangerang.

\section{PEMBAHASAN}

Pada penelitian ini jumlah pasien yang menjalani HD lebih banyak pada >24 bulan yaitu sebanyak 19 orang (54 \%). Dan dari 35 pasien, 18 pasien ( $51 \%$ ) memiliki kualitas hidup yang buruk. Hasil ini sesuai dengan penelitian yang dilakukan oleh Sari ( 2017 ). Berdasarkan hasil analisis didapatkan nilai $\mathrm{p}$ sebesar 0,06 (>0,05) maka dapat diambil kesimpulan bahwa tidak ada hubungan yang signifikan antara lama menjalani HD dengan kualitas hidup pada pasien Penyakit ginjal kronis di Ruang Hemodialisa RS Dr Sitanala Tangerang. 
Hasil penelitian ini tidak sejalan dengan penelitian yang dilakukan oleh Sari pada tahun 2017 yang menyatakan bahwa ada hubungan yang bermakna antara lama menjalani hemodialisis dengan kualitas hidup pasien penyakit ginjal kronik di RSUD Abdul Moeluk Bandar Lampung $(\mathrm{p}=0,002)$. Perbedaan hasil penelitian tersebut kemungkinan terjadi karena adanya variasi data dari para responden. Penelitian lain yang mendukung menyimpulkan tidak terdapat hubungan antara lama menjalani hemodialisis dengan kualitas hidup pasien di beberapa tempat di Indonesia Juga antara lain dilakukan penelitian oleh Rahman, dkk pada tahun 2016 di RSUP Kandou Manado dengan $\left(p\right.$-value > 0,579) ${ }^{15}$ begitu juga hasil penelitian di RSU Cut Meutia Kabupaten Aceh Utara $(p$-value $=0,227)$ dimana tidak ada hubungan yang bermakna antara lama menjalani hemodialisis dengan kualitas hidup (Husna \& Maulina, 2015).

Hasil penelitian Harasyid pada tahun 2011di RSUP Adam Malik Sumatera Utara ( $p$-value > 0,05) dan penelitian Dewi, dkk pada tahun 2015 yang menyatakan tidak ada hubungan antara yang signifikan antara lamanya hemodialisis dengan kualitas hidup pasien gagal ginjal di RS PKU Muhammadiyah Yogyakarta ( $p$-value $=0,739)$.
Namun berdasarkan lamanya terapi menunjukkan bahwa pasien yang menjalani terapi $\geq 2$ tahun memiliki kualitas hidup lebih baik dibandingkan pasien yang menjalani terapi $<2$ tahun. Dikarenakan Semakin lama pasien menjalani terapi hemodialisis maka semakin patuh pasien tersebut, karena biasanya pasien telah mencapai tahap menerima dan merasakan manfaat hemodialisis. Studi analisis Wijayanti, dkk pada 2017, dimana penelitian ini menyatakan kesuksesan hemodialisis tergantung pada kepatuhan pasien menjalani terapi hemodialisis.

Hasil penelitian mendominasi bahwa tidak terbukti adanya hubungan antara lama menjalani hemodialisis dengan kualitas hidup pasien. Hal ini dapat disebabkan karena kualitas hidup merupakan suatu perasaan subjektif yang dimiliki oleh masing-masing individu dan hal ini tidak dipengaruhi oleh faktor eksternal. Hal serupa diungkapkan oleh Nurchayati pada tahun 2011 yang menyatakan bahwa kualitas hidup tidak dapat didefinisikan dengan pasti, hanya individu yang berkaitan yang dapat mendefinisikan karena bersifat sangat subjektif dan pribadi. 
Kualitas hidup pasien gagal ginjal sangat berkaitan dengan terapi hemodialisis Namun, hemodialisis bukan merupakan terapi untuk menyembuhkan namun hemodialisis dilakukan untuk mempertahankan keberlangsungan fungsi kehidupan, dan pada kasus gagal ginjal kronik dimana pasien akan ketergantungan seumur hidup untuk menjalanai terapi hemodialisa. Pasien yang menjalani terapi hemodialisis secara regular akan memiliki kualitas hidup yang lebih baik.

\section{KESIMPULAN}

1. Teridentifikasi distribusi karakteristik pasien dengan Penyakit ginjal Kronis yang menjalani terapi hemodialisis di ruang hemodialisa RS Dr Sitanala Tangerang lebih dari setengah sebanyak 20 responden dengan hasil 57 $\%$ usia >50 tahun dan lebih dari setengah sebanyak 18 responden dengan hasil $51 \%$ laki-laki.

2. Teridentifikasi rata-rata lama pasien Penyakit ginjal Kronis menjalani terapi hemodialisis di ruang hemodialisa RS Dr Sitanala Tangerang hasil lebih dari setengah sebanyak 19 responden dengan hasil $54 \%$ sudah menjalanai terapi hemodialisis selama $\geq 2$ tahun.

3. Teridentifikasi kualitas hidup pasien Penyakit ginjal Kronis yang menjalani terapi hemodialisis di ruang hemodialisa RS Dr Sitanala Tangerang Berdasarkan tabel 4 didapatkan hasil lebih dari setengah sebanyak 18 responden dengan hasil $51 \%$ memiliki kualitas hidup yang buruk.

4. Teridentifikasi hubungan lama menjalani terapi hemodialisa dengan kualitas hidup pasien penyakit ginjal kronik di ruang hemodialisa RS Dr Sitanala Tangerang. Hasil uji statistik menggunakan Chi Square Test diperoleh nilai $p=0,060(p>0,05)$ dapat disimpulkan secara statistik bahwa tidak terdapat hubungan yang bermakna antara lama hemodialisis dengan kualitas hidup pada pasien Penyakit ginjal kronis di Ruang Hemodialisa RS Dr Sitanala Tangerang.

\section{DAFTAR PUSTAKA}

Dewi, S.P., Anita, D.C., \& Syaifudin. (2015). Hubungan Lamanya Hemodialisa dengan Kualitas Hidup Pasien Gagal Ginjal di RS PKU Muhammadiyah Yogyakarta. Naskah Publikasi.

Harasyid, A.M. (2011). Hubungan Lamanya Hemodialisis dengan Kualitas Hidup Pasien Penyakit Ginjal Kronik di RSUP H. Adam Malik Medan, Sumatera Utara.Medan : Universitas Sumatera Utara 
Hill,N.R. Samuel T. Fatoba, Jason L. Oke, Jennifer A. Hirst, Christopher A. O'Callaghan, Daniel S. Lasserson, and F. D. Richard Hobbs. (2016). Global Prevalence of Chronic Kidney Disease - A Systematic Review and Meta-Analysis.Oxford : Nuffield Department of Primary Care Health Sciences

Husna, C. (2010). Gagal ginjal kronis dan penanganannya. Jurnal Keperawatan. Semarang : FIKkes Unimus

Infodatin. (2017). Situasi Penyakit Ginjal kronik. Jakarta : Kementerian kesehatan

Mabsusah, Mabsusah. (2016). Kualitas Hidup (Quality Of Life) Pasien Diabates Mellitus di RSUD Dr. H. Slamet Martodirdjo Kabupaten Pamekasan Madura ( Skripsi ). Surabaya. Universitas Islam Negeri Sunan Ampel Surabaya

National Kidney Foundation. (2013). KDIGO 2012 Clinical Practice Guideline for the Evaluation and Management of Chronic Kidney Disease. New York. National Kidney Foundation

Nur, A.A. (2012). Hubungan Tingkat Depresi Dengan Kualitas Hidup Pasien Gagal Ginjal Kronik di RSU Kota Makassar ( Skripsi). Makassar. Universitas Islam Negeri Alauddin Makassar

Nuari, N.A. dan Dhina Widayati. (2017). Gangguang pada Sistim Perkemihan \& Penatalaksanaan Keperawatan. Yogyakarta : Deepublish
Nurchayati, S. (2010). Analisis faktorfaktor yang berhubungan dengan kualitas hidup pasien penyakit ginjal kronik yang menjalani hemodialisis di Rumah Sakit Islam Fatmawati Cilacap dan Rumah Sakit Umum Daerah Banyumas. Depok : Universitas Indonesia

Pernefri. (2017). 10 th report of Indonesian Renal Registry. Jakarta : Pernefri

Rahman, M.T.S.A., Kaunang, T.M.D., \& Elim, C. (2016). Hubungan antara lama menjalani hemodialisis dengan kualitas hidup pasien yang menjalani hemodialisis di Unit Hemodialisis RSUP. Prof. Dr. R. D. Kandou Manado. Jurnal eClinic (e-CI), Vol. 4. 1. 36-40

Sari,D.K. (2017). Hubungan Lama Menjalani Terapi Hemodialisis dengan Kualitas Hidup Pasien Penyakit Ginjal Kronik di Instalasi Hemodialisis RSUD Abdul Moeloek ( Skripi ). Bandar Lampung. Universitas Lampung

Wijayanti, W., Isroin, L., \& Purwanti, L.E. (2017). Analisis Perilaku Pasien Hemodialisis dalam Pengontrolan Cairan Tubuh. Indonesia Journal for Health Sciences (IJHS). Vol. 1. No. 1. 10-16. ISSN : 2549-2748 